\title{
ANALISIS TERHADAP PENYALAHGUNAAN ALOKASI DANA DESA DIKAITKAN DENGAN TINDAK PIDANA KORUPSI
}

\author{
Oleh: \\ Muhammad Taufikqurrahman \\ Efensisus Bali \\ Universitas Darma Agung, Medan \\ E-mail: \\ mtwawa1234@gmail.com \\ efensiusb@gmail.com
}

\begin{abstract}
Village Funds are funds sourced from the State. Based on the Republic of Indonesia Minister of Finance Regulation number 241 of 2014 article (1) concerning the implementation of accountability for transfers to regions and village funds, village funds are defined as funds sourced from the APBN allocated for and transferred through district and city APBD which are used to finance government administration, development implementation, and community financing. This statement emphasizes that the function of the village fund is to assist the village in financing the needs of the people in the village. The use of Village Funds for other purposes will be known as the practice of village funds which is corruption. The final results of this study indicate that the allocation of village funds in the I hamlet of Percut Village, Percut Sei Tuan District, Deli Serdang Regency has been misused, the defendant is threatened with punishment in Article 2 Paragraph (2) Jo Article 18 of Law No. 31 of 1997 as amended and added. with Law No. 20 of 2001 concerning the eradication of criminal acts of corruption, and based on decision Number 125 / Pid.Sus.TPK / 2017 / PN.Mdn, the panel of judges examining and adjudicating the case handed down a verdict on the defendant, namely the defendant was imprisoned for five years. state detention house, and must pay a court fee of five thousand rupiah.
\end{abstract}

\section{Keywords: Village Funds, Corruption Crime, Misuse of Village Funds}

\begin{abstract}
ABSTRAK
Dana Desa adalah adalah Dana yang bersumber dari Negara. Berdasarkan Permenkeu RI nomor 241 tahun 2014 pasal (1) tentang pelaksanaan pertanggungjawaban tranfer ke daerah dan dana desa, dana desa diartikan sebagai dana yang bersumber dari APBN ynag dperuntukkan bagi dan ditransfer melalui APBD kabupaten dan kota yang digunakan untuk membiayai penyeleggaraan pemerintah, pelaksanaan pembangunan, dan pembiayaan kemasyarakatan. Pernyataan ini menekankan bahwa fungsi dana desa adalah untuk membantu desa dalam membiayai kebutuhan-kebutuhan masyarakat yang ada di desa tersebut. Penggunaan Dana Desa untuk kepentingan lain akan dikenal sabagi praktek penyalahgunaan dana desa yang merupakan korupsi. Hasil akhir penelitian ini
\end{abstract}


menunjukkan bahwa pengalokasian dana desa di dusun I Desa Percut Kecamatan Percut Sei Tuan Kabupaten Deli Serdang telah disalahguakan, terdakwa diancam pidana dalam pasal 2 Ayat (2) Jo pasal 18 Undang-Undang No 31 tahun 1997 sebagai mana telah diubah dan ditambah dengan Undang-Undang no 20 tahun2001 tentang pemberantasan tindak pidana korupsi, dan berdasarkan putusan Nomor 125/Pid.Sus.TPK/2017/PN.Mdn majelis hakim yang memeriksa dan mengadili perkara tersebut menjatuhkan putusan kepada terdakwa, yaitu terdakwa dipenjara lima tahun, ditahan rumah tahanan negara, dan harus membayar biaya perkara sebesar lima ribu rupiah.

\section{Kata Kunci: Dana Desa, Tindak Pidana Korupsi, Penyalahgunaan Anggaran Dana Desa}

\section{PENDAHULUAN}

Secara historis desa merupakan dasar terbentuknya masyarakat politik dan pemerintahan di indonesia. Jauh sebelum bangsa entitas sosial sejenis desa telah menjadi institusi sosial yang sangat penting. Kenyataan ini menadi bukti bahwa desa merupakan dasar terbentunya suatu negara disisi, lain sebagai akibat dari pengertian jaman, desa desa telah berubah fungsi menjadi salah satu unit terkecil pemerintahan yang harus di perhatikan oleh Negara.

Dari berbagai defenisi di atas peneliti menyimpulkan bahwa desa desa merupakan unit terkecil dalam suatu negara dimana terdapat kumpulan masyarakat yang memiliki tempat yang sama untuk keberlangsungan hidup, dan sekaligus merupakan dasar terbentuknya suatu negara.Dalam keberlangsungan hidup,masyarakat yang mendiami suatu desa telah menyepakati aturan aturan tertentu, atauran atauran tersebut berasal dari masyarakat itu sendiri dan luar masyarakat itu sendiri .salah satu contoh aturan yang berasal dari masyarakat yang mendiami suatu desa dikenal sebagai adat istiadat aturan-atauran ini disepakati secara tertulis maupun tidak tertulis. Masyarakat yang tidak hidup dengan aturan tersebut akan menerima sangsi sesuai dengan aturan yang telah di sepakati bersama.

Sistem pemerintahan Negara Kesatuan Indonesia menerapkan Otonomi Daerah. Hal ini memberikan kesempatan kepada daerah-daerah yang ada di seluruh wilayah NKRI untuk membangun daerah sendiri. Disisi lain, negara tidak melepas daera-daerah tersbut begitu saja, melainkan membantu daerah dalam melakukan pembanguna-pembangunan. Salah satu yang dilakukan negara untuk membantu daera-daerah tersebut, terutama di desa, adalah dengan mengadakan Dana Desa.

Dana Desa adalah adalah Dana yang bersumber dari Negara. Berdasarkan Permenkeu RI Nomor 241 tahun 2014 pasal (1) tentang pelaksanaan pertanggungjawaban tranfer ke daerah dan dana desa, dana desa diartikan sebagai dana yang bersumber dari APBN ynag dperuntukkan bagi dan ditransfer melalui APBD kabupaten dan kota yang digunakan untuk membiayai penyeleggaraan pemerintah, pelaksanaan pembangunan, dan pembiayaan kemasyarakatan. 
Pernyataan ini menekankan bahwa fungsi dana desa adalah untuk membantu desa dalam membiayai kebutuhan-kebutuhan masyarakat yang ada di desa tersebut.

Penggunaan Dana Desa untuk kepentingan lain akan dikenal sabagi praktek penyalahgunaan dana desa yang merupakan korupsi. Prodjodikoro mendenifisikan korupsi sebagai suatu perbuatan yang pelakunya dapat di kenakan tindak pidana. Pernyataan ini menekankan bahwa tindakan apapun yang menyebabkan pelaku dapat dikenakan tindak pidana disebut sebagai korupsi.

\section{TINJAUAN PUSTAKA}

\section{Konsep alokasi Dana Desa}

Keuangan memiliki makna yang berbeda-beda menurut para ahli. Desa adalah semua hak dan kewajiban desa yang dapat dinilai dengan uang serta segala sesuatu berupa uang dan barang yang berhubungan dengan pelaksanaan hak dan kewajiban Desa. Hak dan kewajiban menimbulkan pendapatan, belanja, pembiayaan, dan pengelolaan Keuangan Desa.

Pendapatan Desa bersumber dari:

1. Pendapatan asli Desa terdiri atas hasil usaha, hasil aset, swadaya dan partisipasi, gotong royong, dan lain-lain pendapatan asli Desa;

2. Alokasi Anggaran Pendapatan dan Belanja Negara;

3. Bagian dari hasil pajak daerah dan retribusi daerah Kabupaten/Kota;

4. Alokasi dana Desa yang merupakan bagian dari dana perimbangan yang diterima Kabupaten/Kota;

5. Bantuan keuangan dari Anggaran Pendapatan dan
Belanja Daerah Provinsi dan Anggaran Pendapatan dan Belanja Daerah Kabupaten/Kota;

6. Hibah dan sumbangan yang tidak mengikat dari pihak ketiga; dan

7. Lain-lain pendapatan Desa yang sah.

Dana Desa adalah dana yang bersumber dari Negara. Berdasarkan Permenkue RI Nomor 241 tahun 2014 pasal (1) tentang pelaksanaan pertanggung jawaban tranfer ke daerah dan dana desa, dana desa diartikan sebagai dana yang bersumber dari APBN ynag dperuntkkjan bagi dan di transfer melalui APBD kabupaten dan kota yang digunakan untuk membiayai penyeleggaraan pemerintah, pelaksanaan pemangunan, dan pembiayaan kemasyarakatan. Menurut Pasal 1 angka 9 Peraturan Pemerintah Nomor 47 Tahun 2015 tentang Perubahan Atas Peraturan Pemerintah Nomor 43 Tahun 2014 tentang Peraturan Pelaksanaan Undang-Undang Nomor 6 Tahun 2014 tentang Desa ("PP 47/2015") yang dimaksud dengan Alokasi Dana Desa ("ADD") adalah dana perimbangan yang diterima kabupaten/kota dalam Anggaran Pendapatan dan Belanja Daerah kabupaten/kota setelah dikurangi Dana Alokasi Khusus. Pemerintah daerah kabupaten/kota mengalokasikan dalam anggaran pendapatan dan belanja daerah kabupaten/kota ADD setiap tahun anggara. ADD tersebut paling sedikit $10 \%$ dari dana perimbangan yang diterima kabupaten/kota dalam Anggaran Pendapatan dan Belanja Daerah setelah dikurangi Dana Alokasi Khusus. Dalam rangka pengelolaan Keuangan Desa, Kepala 
Desa melimpahkan sebagian kewenangan kepada perangkat Desa yang ditunjuk. Bagi Kabupaten/Kota yang tidak memberikan ADD Pemerintah dapat melakukan penundaan dan/atau pemotongan sebesar alokasi dana perimbangan setelah dikurangi Dana Alokasi Khusus yang seharusnya disalurkan ke Desa.

\section{Pertimbangan penyaluran} ADD

Ada beberapa hal perlu diperimbangkan dalam penyaluran dana desa. Hal-hal tersebut meliputi kebutuhan penghasilan tetap kepala desa dan perangkat desa, jumlah penduduk desa, angka kemiskinan desa, luas wilayah desa, dan tingkat kesulitan geografis desa. Ketentuan mengenai pengalokasian ADD dan pembagian ADD kepada setiap desa ditetapkan dengan peraturan bupati/walikota. Jadi, salah satu sumber pendapatan desa adalah ADD yang merupakan bagian dari dana perimbangan yang diterima kabupaten/kota. ADD tersebut paling sedikit $10 \%$ (sepuluh perseratus) dari dana perimbangan yang diterima Kabupaten/Kota dalam Anggaran Pendapatan dan Belanja Daerah setelah dikurangi Dana Alokasi Khusus.

Ada beberapa pendapat ahli tentang pengelolaan ADD.

a Secara sepesifik, ada beberapa tahapan dalam pengeloaan Alokasi Dana Desa. Menurut Peraturan Bupati Batanghari Nomor 3 Tahun 2014 tentang Pedoman Pengelolaan Alokasi Dana Desa Kabupaten Batanghari, Tahun 2014 Alokasi Dana Desa diatur secara rinci mulai dari tahap perencanaan, pelaksanaan, dan pertanggungjawaban. Masing- masing bagian tersebut dijelaskan dalam penjelasan sebagai berikut:

\section{a. Tahap Perencanaan}

Mekanisme perencanaan Alokasi Dana Desa dimulai dari Kepala Desa selaku penanggung jawab Alokasi Dana Desa mengadakan musyawarah desa untuk membahas rencana penggunaan Alokasi Dana Desa yang dihadiri oleh unsur pemerintah desa, Badan Permusyawaratan Desa, lembaga kemasyarakatan desa, dan tokoh masyarakat. Hasil musyawarah tersebut dituangkan dalam Rancangan Penggunaan Dana (RPD) yang merupakan salah satu bahan penyusunan APBDes.

\section{b. Tahap pelaksanaan}

Pelaksanaan

kegiatan sebagaimana ditetapkan dalam APBDes yang pembiayaannya bersumber dari Alokasi Dana Desa sepenuhnya dilaksanakan oleh Tim Pelaksana Desa. Selanjutnya guna mendukung keterbukaan dan penyampaian informasi secara jelas kepada masyarakat, maka pada setiap pelaksanaan kegiatan fisik Alokasi Dana Desa wajib dilengkapi dengan papan informasi kegiatan yang di pasang di lokasi kegiatan.

\section{c. Tahap} pertanggungjawaban

Pertanggung jawaban Alokasi Dana Desa terintegrasi dengan pertanggung jawaban pelaksanaan APBDes sesuai dengan Peraturan Bupati Batanghari Nomor 47 Tahun 2014 tentang Pedoman Pengelolaan Keuangan Desa. Namun demikian, Tim Pelaksana Alokasi Dana Desa wajib melaporkan pelaksanaan Alokasi Dana Desa yang berupa Laporan Bulanan, yang mencakup perkembangan pelaksanaan dan penyerapan dana, serta laporan kemajuan fisik pada setiap tahapan 
pencairan Alokasi Dana Desa yang merupakan gambaran kemajuan kegiatan fisik yang Dilaksanakan.

\section{METODE PELAKSANAAN}

Penelitian ini menggunakan studi kasus normative yang berupa produk perilaku hukum. Pokok kajian dari penelitian dengan jenis ini adalah berupa hukum yang dikonsepkan sebagai norma atau kaidah yang berlaku dalam masyarakat dan menjadi acuan perilaku setiap orang.

Penelitian ini berfokus pada data primer yang bersumber dari Putusan nomor 125/Pid.Sus,TPK/2017/PN,Mdn.

Peneliti mengumpulkan data yang berupa hasil putusan pengadilan negeri medan yang mengadili tindak pidana penyalagunaan alokasi dana desa dengan acara pemeriksaan biasa pada peradilan tingkat pertama terdakwa dalam kasus ini merupakan perangkat desa yang mengelola dana desa di kecamatan percut kabupaten Deli Serdang. Data lain dari penelitian ini adalah data sekunder. Data ini berasal dari UU no. 6 tahun 2014 tentang Desa dan UU RI no. 20 tahun 2001 tentang pemberantasan tindak pidana korupsi.serta putusan Nomor

125/Pid.Sus/TPK/2017/PN.Mdn

IV. HASIL DAN PEMBAHASAN Penyalahgunaan Dana Desa Percut Sei Tuan Kabupaten Deli Serdang Berdasarkan Putusan Nomor 125/Pid.Sus.Tpk/2017/Pn.Mdn

Dana Desa sebesar Rp. 782.383.000,- (tujuh ratus delapan puluh dua juta tiga ratus delapan puluh tiga ribu rupiah) sesuai Peraturan Bupati Deli Serdang Nomor : 714 Tahun 2016 tanggal 12 Mei 2016 tentang Tata Cara
Pembagian, Penetapan Perincian dan Pedoman Teknis Penggunaan Dana Desa di Kabupaten Deli Serdang Tahun anggaran 2016 yang sumber dananya adalah dari Anggaran Pendapatan Belanja Negara (APBN).

Dana Desa yang berjumlah Rp.655.310.000, (enam ratus lima puluh lima juta tiga ratus sepuluh ribu rupiah) dan Bagian Hasil Pajak Daerah dan Retribusi Daerah sebesar Rp. 69.646.000,- (enam puluh sembilan juta enam ratus empat puluh enam ribu rupiah) sesuai Keputusan Bupati Deli Serdang Nomor 591 Tahun 2016 tanggal 21 April 2016 tentang Besaran Alokasi Dana Desa (ADD) dan Bagian Hasil Pajak Daerah dan Retribusi Daerah Yang Diterima Setiap Desa SeKabupaten Deli Serdang Tahun 2016 yang sumber dananya adalah dari Anggaran Pendapatan Belanja Daerah Kabupaten Deli Serdang.

Tahun anggaran 2015 sebesar Rp. 321.022.400,- (tiga ratus dua puluh satu juta dua puluh dua ribu empat ratus rupiah) Bahwa sesuai Peraturan Desa Percut Kecamatan Percut Sei Tuan Kabupaten Deli Serdang Nomor 02 Tahun 2016 tanggal 27 Agustus 2016 tentang Anggaran Pendapatan dan Belanja Desa (APBDes) Desa Percut Tahun Anggaran 2016 Anggaran Pendapatan dan Belanja Desa (APBDes) sebesar Rp. 1.828.361.400, (satu milyar delapan ratus dua puluh delapan juta tiga ratus enam puluh satu ribu empat ratus rupiah) tersebut akan dipergunakan untuk kegiatan Bidang Penyelenggaraan Pemerintahan Desa Rp 600.558.900 Bidang Pelaksanaan Pembangunan Desa Rp. 1.202.513.400,-

Bidang Pembinaan Kemasyarakatan Rp. 21.614.100, Bidang Pemberdayaan Masyarakat Rp 
3.675.000, Bahwa sesuai Lampiran Peraturan Desa Percut Nomor 02 Tahun 2016 tanggal 27 Agustus 2016 tentang Anggaran Pendapatan dan Belanja Desa (APBDes).

Anggaran Pendapatan dan Belanja Desa (APB-Des) Desa Percut Kecamatan Percut Sei Tuan Kabupaten Deli Serdang pada tahun anggaran 2016 adalah sebesar Rp. 1.828.361.400,- (satu milyar delapan ratus dua puluh delapan juta tiga ratus enam puluh satu ribu empat ratus rupiah) yang diperoleh dari Pendapatan Transfer, yaitu:

1. Dana Desa sebesar Rp. 782.383.000,- (tujuh ratus delapan puluh dua juta tiga ratus delapan puluh tiga ribu rupiah) sesuai Peraturan Bupati Deli Serdang Nomor : 714 Tahun 2016 tanggal 12 Mei 2016 tentang Tata Cara Pembagian, Penetapan Perincian dan Pedoman Teknis Penggunaan Dana Desa di Kabupaten Deli Serdang Tahun anggaran 2016 yang sumber dananya adalah dari Anggaran Pendapatan Belanja Negara (APBN).

2. Alokasi Dana Desa sebesar Rp.655.310.000,- (enam ratus lima puluh limajuta tiga ratus sepuluh ribu rupiah) dan Bagian Hasil Pajak Daerah dan Retribusi Daerah sebesar Rp. 69.646.000,- (enam puluh sembilan juta enam ratus empat puluh enam ribu rupiah) sesuai Keputusan Bupati Deli Serdang Nomor 591 Tahun 2016 tanggal 21 April 2016 tentang Besaran Alokasi Dana Desa (ADD) dan Bagian Hasil Pajak Daerah dan Retribusi Daerah Yang Diterima Setiap Desa Se-Kabupaten Deli Serdang Tahun 2016 yang sumber dananya adalah dari
Anggaran Pendapatan Belanja Daerah Kabupaten Deli Serdang.

3. Sisa Lebih Pengunaan Anggaran (SILPA) tahun anggaran 2015 sebesar Rp. 321.022.400,- (tiga ratus dua puluh satu juta dua puluh dua ribu empat ratus rupiah).

Sesuai Peraturan Desa Percut Kecamatan Percut Sei Tuan Kabupaten Deli Serdang Nomor 02 Tahun 2016 tanggal 27 Agustus 2016 tentang Anggaran Pendapatan dan Belanja Desa (APBDes) Desa Percut Tahun Anggaran 2016 Anggaran Pendapatan dan Belanja Desa (APBDes) sebesar Rp. 1.828.361.400,(satu milyar delapan ratus dua puluh delapan juta tiga ratus enam puluh satu ribu empat ratus rupiah) tersebut akan dipergunakan untuk kegiatan:
a) Bidang Pemerintahan Desa Rp. 600.558.900,
b) Bidang Pembangunan Desa Rp. 1.202.513.400,
c) Bidang Pembinaan Kemasyarakatan Rp. 21.614.100,
d) Bidang Pemberdayaan Masyarakat Rp. 3.675.000,-
Sesuai Lampiran Peraturan Desa Percut Nomor 02 Tahun 2016 tanggal 27 Agustus 2016 tentang Anggaran Pendapatan dan Belanja Desa (APBDes) Desa Percut tahun 2016, item-item pekerjaan Bidang Pelaksanaan Pembangunan Desa tersebut adalah :
a) Pembangunan Drainase Dusun VI Rp. 279.416.000,
b) Pembangunan Drainase Dusun VII Rp. 150.134.000,
c) Pembangunan Drainase Dusun IX Rp. 141.281.000,
d) Pembangunan Drainase Dusun XI Rp. 150.134.000,


e) Pembangunan Drainase Dusun XII Rp. 61.418.000,

f) Pembangunan Gorong-Gorong Dusun XIV Rp. 24.750.000,

g) Pembangunan Gorong-Gorong Dusun VI Rp. 24.750.000,

h) Pengerasan Jalan Sertu Dusun IV dan Dusun VI Rp. 52.691.000,

i) Pengerasan Jalan di Dusun XVIII Rp. 52.691.000,

j) Lanjutan Pembangunan Drainase Dusun XII Rp. 70.306.400,

k) Pembangunan Drainase Dusun III Rp. 89.936.000,

1) Penghijauan Rp. 48.646.000,

m) Pelayanan Kesehatan Desa Rp. 22.860.000,

n) Pengembangan dan Pembinaan Sanggar Seni Rp. 12.500.000,

o) Ongkos Angkut Raskin Rp. 21.000.000,-

Bahwa sesuai Rekening Koran Tabungan Bendahara Desa Percut dengan nomor rekening 109.02.04.018189-5 pada PT. Bank Sumut Cabang Tembung Periode 01 Januari 2016 s/d 31 Desember 2016 bahwa APB-Des Desa Percut tahun anggaran 2016 tersebut sudah dicairkan sebesar Rp. 1.828.360.960,- (satu milyar delapan ratus dua puluh delapan juta tiga ratus enam puluh ribu sembilan ratus enam puluh rupiah) yaitu:
a) Tanggal 07 Juni 2016: Rp. 64.140.000,
b) Tanggal 07 Juni 2016: Rp. 5.250.000,
c) Tanggal 30 Juni 2016: Rp. 3.500.000,
d) Tanggal 30 Juni 2016: Rp. 42.760.000,
e) Tangal 07 September 2016: Rp. 3.500 .000
f) Tangal 07 September 2016: Rp. 42.760.000,

g) Tanggal 15 Sptember 2016:Rp. 182.263.000,

h) Tanggal 04 Oktober 2016: Rp. 138.759.360,

i) Tanggal 10 Oktober 2016: Rp. 389.384.000,

j) Tanggal 02 Nopember 2016: Rp. 42.760.000,

k) Tanggal 02 Nopember 2016: Rp. 3.500.000,

1) Tanggal 04 Nopember 2016: Rp. 348.483.000,

m) Tanggal 23 Desember 2016: Rp. 178.958.400,

n) Tanggal 23 Desember 2016: Rp. 64.140.000,

o) Tanggal 23 Desember 2016: Rp. 5.250.000,

p) Tanggal 29 Desember 2016: Rp. 312.953.200,-

Sisanya Rp. 440.000 (empat ratus empat puluh rupiah) merupakan saldo di Bank bahwa mekanisme pencairan Anggaran Pendapatan dan Belanja Desa (APB-Des) Desa Percut Kecamatan Percut Sei Tuan tahun 2016 adalah TerdakwaChairil Anwar, S.Pd. selaku Kepala Desa Percut membuat permohonan pencairan dana tahun 2016 yang ditujukan kepada Bupati Deli Serdang cq Kepala Badan Pemberdayaan Masyarakat Kabupaten Deli Serdang, kemudian setelah uang masuk ke rekening desa Percut pada PT. Bank Sumut Cabang Tembung Nomor rekening 189.02.04.018189-5 Terdakwa Chairil Anwar, SPd selaku Kepala Desa bersama Bendahara Desa Percut pergi ke Bank Sumut Cabang Tembung untuk melakukan pencairan Anggaran Desa Percut tahun 2016 tersebut dengan cara Terdakwa Chairil Anwar, S.Pd. bersama Bendahara menandatangani slip pengambilan uang. 
Sesuai Peraturan Desa Percut Nomor 01 Tahun 2017 tanggal 20 Januari 2017 tentang Laporan Realisasi Anggaran Pendapatan dan Belanja Desa (APB-Des) Desa Percut Tahun 2016 yang ditandatangani Terdakwa Chairil Anwar, S.Pd. dan disampaikan ke Kantor Camat Percut Sei Tuan dan selanjutnya ke Dinas Pemberdayaan Masyarakat dan Desa Kabupaten Deli Serdang dari Anggaran Pendapatan dan Belanja Desa Percut Tahun Anggaran 2016 sebesar Rp. 1.828.361.400,- (satu milyar delapan ratus dua puluh delapan juta tiga ratus enam puluh satu ribu empat ratus rupiah), realisasi penggunaannya adalah sebesar Rp. 1.825.361.400,- (satu milyar delapan ratus dua puluh lima juta tiga ratus enam puluh satu ribu empat ratus rupiah) karena ada SILPA Tahun anggaran 2016 sebesar Rp. 3.000 .000 ,- (tiga juta rupiah) yaitu dari anggaran ongkos angkut raskin. Bahwa pada tahun anggaran 2016 pekerjaan Bidang Pelaksanaan Pembangunan Desa yaitu Pembangunan Drainase Dusun IX dengan anggaran sebesar Rp. 141.281.000,- (seratus empat puluh satu juta dua ratus delapan puluh satu ribu rupiah) dan Pembangunan Drainase Dusun XI dengan anggaran sebesar Rp. 150.134.000 (seratus lima puluh juta seratus tiga puluh empat ribu rupiah) tidak ada dilaksanakan sama sekali, namun pada tanggal 29 Desember 2016 anggaran Pembangunan Drainase Dusun IX sebesar Rp. 141.281.000, dan anggaran Pembangunan Drainase Dusun XI sebesar Rp. 150.134.000,- tersebut sudah dicairkan Terdakwa Chairil Anwar, S.Pd. selaku Kepala Desa Percut bersama Juliana selaku Bendahara
Desa Percut dari rekening Desa Percut dan setelah anggaran tersebut dicairkan Terdakwa Chairil Anwar, SPd meminta uang tersebut dari Juliana dengan alasan untuk pelaksanaan Pekerjaan Pembangunan Drainase Dusun IX dan Pekerjaan Drainase Dusun XI sebesar Rp. 270.000.000,- (dua ratus tujuh puluh juta rupiah) dengan rincian pada tanggal 29 Desember 2016 sebesar Rp. 200.000.000,- (dua ratus juta rupiah) dan pada tanggal 30 Desember 2016 sebesar Rp. 70.000.000,- (tujuh puluh juta rupiah) sedangkan sisanya $\mathrm{Rp}$. 21.415.000,- (dua puluh satu juta empat ratus lima puluh ribu rupiah) disimpan Juliana selaku Bendahara. Bahwa pekerjaan Bidang Pelaksanaan Pembangunan Desa yaitu Pembangunan Drainase Dusun IX dengan anggaran sebesar Rp. 141.281.000 dan Pembangunan Drainase Dusun XI dengan anggaran sebesar Rp 150.134.000, tersebut sama sekali tidak dilaksanakan namun pada tanggal 09 dan Pajak februari 2017 dibayarkan Pajak Pertambahan Nilai (PP) Penghasilan $(\mathrm{PPh})$ yaitu untuk pekerjaan Pembangunan Drainase Dusun IX PPn sebesar Rp. 12.844.000,- (dua belas juta delapan ratus empat puluh empat ribu rupiah) dan $\mathrm{PPh}$ sebesar Rp. 1.926.000,- (satu juta sembilan ratus dua puluh enam ribu rupiah) dan untuk pekerjaan Pembangunan Drainase Dusun XI PPn sebesar Rp. 13.649.000,- (tiga belas juta enam ratus empat puluh sembilan ribu rupiah) dan $\mathrm{PPh}$ sebesar Rp. 2.047.000,- (dua juta empat puluh tujuh ribu rupiah) pada tanggal 09 Pebruari 2017. Sehingga, jumlah keseluruhannya Rp. 30.466.000,(tiga puluh juta empat ratus enam puluh enam ribu rupiah). Bahwa dari 
dana sebesar Rp. 270.000.000,- (dua ratus tujuh puluh juta rupiah) yang diminta Terdakwa Chairil Anwar, S.Pd. dari Juliana selaku Bendahara Desa anggaran Pekerjaan Pembangunan Drainase Dusun IX dan Pekerjaan Drainase Dusun XI tersebut pada tanggal 09 Pebruari 2017 sebesar Rp.9.051.000,(sembilan juta lima puluh satu ribu rupiah) diserahkan kembali oleh Terdakwa Chairil Anwar, SPd kepada Juliana selaku Bendahara Desa untuk menambahi Pembayaran $\mathrm{PPn}$ dan $\mathrm{PPh}$ atas Pekerjaan Pembangunan Drainase Dusun IX dan Pekerjaan Drainase Dusun XI tersebut sedangkan sisanya sebesar Rp. 260.949.000 (dua ratus enam puluh juta sembilan ratus empat puluh sembilan ribu rupiah) dipergunakan Terdakwa Chairil Anwar, SPd untuk kepentingan dirinya sendiri dan penggunaan dana sebesar Rp. 260.949.000,- (dua ratus enam puluh juta sembilan ratus empat puluh sembilan

ribu rupiah) tersebut tidak didukung bukti pengeluaran yang lengkap dan sah. Bahwa akibat perbuatan Terdakwa Chairil Anwar, SPd yang secara melawan hukum menyalahgunakan anggaran Pekerjaan Pembangunan Drainase Dusun IX dan Anggaran pekerjaan Pembangunan Drainase Dusun XI sebesar Rp. 260.949.000,- (dua ratus enam puluh juta sembilan ratus empat puluh Sembilan ribu rupiah) tersebut telah memperkaya diri Terdakwa sendiri sehingga mengakibatkan kerugian keuangan negara dalam hal ini Pemerintah Kabupaten Deli Serdang sebesar kurang lebih Rp. 260.949.000,- (dua ratus enam puluh juta sembilan ratus empat puluh sembilan ribu rupiah) atau setidak-tidaknya sejumlah itu
Perbuatan Terdakwa sebagaimana diatur dan diancam pidana dalam Pasal 2 Ayat (1) Jo. Pasal 18 Undang-Undang Nomor 31 Tahun 1999 sebagaimana telah diubah dan ditambah dengan Undang Undang Nomor 20 Tahun 2001 tentang Pemberantasan Tindak Pidana Korupsi.

\section{KESIMPULAN}

Terdakwa Chairil Anwar yang secara melawan hukum menyahlahgunakan anggaran pekerjaan pembangunan Drainese dusun IX sebesar Rp.260.949.000 rupiah tersebut telah memperkaya diri sendiri sehingga mengakibatkan kerugian keuangan negara dalam hal ini Kabupaten Deli Serdang sebesar kurang lebih 260.949.000 rupiah. Perbuatan terdakwa diancam pidana dalam pasal 2 Ayat (2) Jo pasal 18 Undang-Undang No 31 tahun 1997 sebagai mana telah diubah dan ditambah dengan Undang-Undang No. 20 tahun2001 tentang pemberantasan tindak pidana korupsi.

Analisis penyahlahgunaan alokasi dana desa yang dikaitkan dengan tindak pidana korupsi didalam pengalokasian dana desa tersebut banyak hal yang terjadi misalnya korupsi angaran tersebut seperti yang terjadi di dusun I Desa Percut Kecamatan Percut Sei Tuan Kabupaten Deli Serdang yang telah menyalahgunakan anggaran dana desa yang telah dijatuhkan pidana terhadap terdakwa dengan pidana 5 (lima) tahun dan dikurangi selama terdakwa berada dalam tahanan sementara denda yang harus dibayarkan sebesar RP.200.000.000 (dua ratus juta rupiah) dan jika denda tersebut tidak dibayarkan maka terdakwa Chairil Anwar, 
S.Pd. harus mengganti dengan hukuman selama 6 (enam) bulan serta uang ganti rugi sebesar Rp260.949.000, (dua ratus enem puluh juta sembilan ratus empat puluh sembilan ribu rupiah) dan jika terdakwa tidak dapat membayar denda uang pengganti paling lama 1 (satu) bulan sesudah putusan pengadilan berkekuatan tetap maka harta bendanya dapat disita oleh jaksa dan dilelang dan jika terdakwa tidak mempunyai harta benda maka terdakwa Chairil Anwar dipidana selama 1 (satu) tahun.

\section{DAFTAR PUSTAKA}

\section{A. Buku-Buku}

A Hamza, 2010. Pengalokasian Dana Desa. Penerbit Sinar Grafika: Jakarta Timur.

Khoiria \& Meiliana, 2017. Pemahaman tentang kedudukan desa di Indonesia. Talenta Raya: Jakarta.

Koentjoroningrat, 2019. Pemahaman Tentang Penelitian Kualitatif. Balai Pustaka: Jakarta.

Masiha, 2018. Penyalahgunaan DanaDesa. Perpustakaan online KEPRI: Tanjungpinang.

Nazir, 2017. Analisis penelitian kualitatif. Rafika: Bandung

Post Media, 2018. Pernyataan Resmi Presiden RI. Post Media: Jakarta.

Projodikoro, 2018. Analisis Penyalahgunaan Dana Desa di Kabupaten

Bintan. Perpustakaan online KEPRI: Tanjungpinang.

Santoso, P. 2012. Administrasi Publik dalam Teori dan Aplikasi Good Governance. PT.Rafika Aditama, Bandung.

Suhartono. 2001. Pedesaaan di Indonesia. Sarana Komunikasi: Jakarta.
Wahyuddin. 2016. Implementasi Kebijakan Alokasi Dana Desa di Desa Ako Kecamatan Pasangkayu Kabupaten Mamuju Utara. Universitas Tadulako, Mamuju.

Widodo, J. 2020. Pengelolaan Dana Desa. Tempo: Jakarta.

\section{A. Perundang-undangan}

Undang-Undang nomor 3 tahun 2014, tentang Pedoman Pengelolaan Alokasi Dana Desa.

Undang-Undang No.20, tentang Perubahan atas UndangUndang No.31 Tahun 1999 tentang Pemberantasan Tindak Pidana Korupsi, 2001.

Undang-Undang Nomor 30 Tahun 2002 tentang Komisi Pemberantasan Tindak Pidana Korupsi.

Undang-Undang Republik Indonesia Nomor 30 Tahun 2002, tentang Komisi Pemberantasan Tindak Pidana Korupsi.

Undang-Undang No. 31 tahun1999, tentang Pemberatasan Tindak Pidana Korupsi.

Undang-Undang Republik Indonesia Nomor 31 Tahun 1999 sebagaimana diubah dengan Undang-Undang Nomor 20 Tahun $2001 \quad$ tentang Pemberantasan Tindak Pidana Korupsi. 